\title{
HUBUNGAN STUNTING DENGAN USIA MENARCHE PADA REMAJA PUTRI DI POSYANDU REMAJA PUSKESMAS IBRAHIM ADJIE
}

\author{
Lia Nurwiliani, Nisa Suci Erlinda \\ Poltekes TNI AU Ciumbuleuit Bandung \\ (My.Liaku@gmail.com)
}

\begin{abstract}
ABSTRAK
Menarche adalah menstruasi pertama yang biasa terjadi dan merupakan ciri khas kedewasaan seorang wanita yang sehat dan tidak hamil. Dewasa ini usia menarche bergeser menjadi lebih muda, namun masih ada remaja yang mengalami menarche terlambat salah satu faktor penyebabnya status gizi kronik (TB/U). Tujuan penelitian ini untuk mengetahui hubungan stunting dengan usia menarche pada remaja putri usia 10-15 tahun. Metode penelitian yang digunakan adalah analitik cross-sectional. Penelitian ini dilakukan di rw 5, 7, 8, 11 Cibangkong dan rw 8 Kebon Waru Posyandu Remaja pada bulan Juni, semua responden yang memenuhi syarat inklusi sebanyak 81 responden. Instrumen penelitian yang digunakan google form dan software WHO Anthros Plus. Penelitian ini menggunakan total sampling, dan uji chi square. Hasil penelitian menunjukan sebagian besar responden tidak mengalami stunting $(80,2 \%)$, dan mengalami usia menarche normal $(53,1 \%)$, hasil uji statistik didapatkan $p$-value $0,02 \quad(p<0,05)$. Simpulan terdapat hubungan stunting dengan usia menarche pada remaja putri usia 10-15 tahun di Posyandu Remaja Wilayah Kerja Puskesmas Ibrahim Adjie.
\end{abstract}

Kata kunci: Status gizi. Stunting, Usia menarche

\begin{abstract}
Menarche is the first menstruation that is common and is a hallmark of the maturity of a healthy woman and not pregnant. Nowadays menarche age shifts to younger, but there are still teenagers who experience late menarche one of the factors causing chronic nutritional status (height/ age). The purpose of this study was to determine the relationship of stunting with menarche age in adolescent girls aged 10-15 years. The research method used was cross-sectional analytic. This research was conducted in $r w 5$, 7, 8, 11 cibangkong and rw 8 kebon waru posyandu adolescents in June, all respondents who met the inclusion requirements were 81 respondents. The research instrument used is the Google form and the WHO Anthros Plus software. This research uses total sampling, and the statistic test chi square. The results showed that most respondents did not experience stunting (80.2\%), and experienced normal menarche age (53.1\%). Statistical test results obtained $p$-value $0.02(p<0.05)$. The conclusion is that there is a relationship between stunting and menarche age in girls aged 10-15 years in adolescent posyandu puskesmas ibrahim adjie.
\end{abstract}

Keywords: Nutritional Status, Stunting, Age of Menarche 


\section{PENDAHULUAN}

Menarche adalah menstruasi pertama yang biasa terjadi dalam rentan usia 10-16 tahun atau pada masa awal remaja di tengah masa pubertas sebelum memasuki masa reproduksi. (Proverati et al, 2010) Menarche, periode menstruasi pertama, adalah biomarker penting dalam kehidupan reproduksi perempuan (Sloboda et al,2007.) Hal ini berhubungan dengan tingkat status kesehatan yang mempengaruhi kesejahteraan perempuan di tahap kehidupan selanjutnya. Usia saat menarche semakin mendapat perhatian karena beberapa penelitian menunjukkan adanya penurunan usia menarche. (Sudikno et al, 2019)

Berdasarkan data Riskesdas 2010 kejadian menarche usia 10-12 tahun $(22,1 \%)$, usia 13 tahun $(20,0 \%)$ dan pada usia $14-15$ tahun $(32,7 \%)$. Hal ini disebabkan oleh peran gizi dan status ekonomi pada usia menarche yang menyebabkan adanya perubahan hormon yang mempengaruhi kematangan sel dan paparan estrogen yang berasal dari konsumsi makanan ataupun rangsangan dari luar. (Riskesdas: 2010)

Menurut World Health Organization (WHO), menarche yang makin dini memungkinkan remaja putri lebih cepat bersentuhan dengan kehidupan seksual sehingga kemungkinan remaja untuk hamil dan menjadi seorang ibu semakin besar. Berdasarkan data Riskesdas 2013 sebanyak
2,6 persen menikah pertama kali di usia < 15 tahun dan 23,9 persen menikah pada usia 15-19 tahun. Menikah pada usia dini merupakan masalah kesehatan reproduksi karena semakin muda usia menikah akan semakin panjang rentang waktu untuk bereproduksi. Angka kelahiran penduduk perempuan antara usia 15-40 tahun adalah 2,68 persen, kelahiran pada usia 15 tahun adalah 0,02 persen meskipun sangat kecil namun memiliki risiko yang tinggi terhadap ibu dan bayi. Kehamilan pada umur remaja usia 15-19 tahun sebesar 1,97 persen. Kehamilan di usia muda akan mempengaruhi tingkat fertilitas di Indonesia jika tidak dilakukan pengaturan kehamilan melalui program KB (Riskesdas, 2013).

Sebaliknya, menarche yang lambat juga berdampak terhadap lambatnya kematangan fisik, baik hormon maupun organ tubuh. Menarche terlambat menyebabkan menopause makin cepat, sehingga masa reproduksi menjadi lebih singkat. Akibat dari menopause mengakibatkan kadar estrogen dan progesteron turun dengan dramatis karena ovarium berhenti merespon FSH dan LH yang diproduksi oleh kelenjar hipofisis yang ada di otak sehingga menyebabkan osteoporosis, gangguan kardiovaskuler, dan stroke yang disebabkan oleh defisiensi estrogen.(Shah et al,2012) 
Selain itu juga, menarche yang terlambat dalam jangka panjang akan meningkatkan risiko perempuan terserang osteoporosis karena lambatnya produksi estrogen yang akan mempengaruhi penentuan masa tulang. Berdasarkan kelompok umur, osteoporosis terbanyak diderita oleh kelompok umur 35-59 tahun sebanyak 1.352 orang. Menarche terlambat disebabkan karena hormonal, kurangnya hormon LH dan FSH atau yang disebut dengan hormon gonadotropin ini bisa menjadi salah satu penyebab menarche terlambat.(Prawirohardjo,2010) Selain hormonal, menarche terlambat bisa disebabkan riwayat usia menarche ibu, semakin cepat ibu mengalami menarche, semakin cepat remaja putri memperoleh menarche, begitupun sebaliknya. Penyakit kronis seperti diabetes, hipotiroid dan hipertiroid menyebabkan menarche menjadi terlambat karena konsumsi dari obat obatan tersebut dapat mempengaruhi siklus hormon pada anak perempuan sehingga mempengaruhi datangnya menarche. Gaya hidup seperti latihan fisik yang berat dapat menunda menarche melalui mekanisme hormonal karena menurunkan produksi progesteron dan akibatnya kematangan endometrium (lapisan dinding rahim) menjadi tertunda. Status gizi merupakan faktor yang berpengaruh terhadap usia menarche. Status gizi yang baik mempengaruhi kematangan seksual perempuan untuk mendapatkan menarche yang tepat, dibandingkan dengan perempuan yang memiliki status gizi kronis.(Nurilah,2012)

Berdasarkan hasil Riset Kesehatan Dasar tahun 2013, prevalensi stunting pada anak usia 5-18 tahun menurut jenis kelamin, pada anak laki-laki prevalensi stunting adalah 40,2\%, sedangkan pada anak perempuan sebesar 35,8\%.(Riskesdas,2013) Anak perempuan yang mengalami stunting akibat kekurangan gizi dalam jangka waktu lama akan mempengaruhi perkembangannya saat memasuki remaja. Anak-anak yang stunting cenderung tetap menjadi pendek selama masa remaja dan dewasa. Hal ini yang akan mempengaruhi perkembangan reproduksinya saat masa pubertas.(Shah et $a l, 2012)$

Hasil Penelitian Nurilla Amaliah menunjukan bahwa remaja berstatus gizi Stunting mengalami menarche lebih lambat dari remaja yang berstatus gizi normal. (Nurilla,2012) Pada remaja stunting perkembangan reproduksinya menjadi terhambat, hal ini menyebabkan hormon yang dihasilkan oleh kelenjar hypotalamus, pituitary terhambat sehingga menyebabkan menarche terlambat.(Shah et al,2012)

Puskesmas Ibrahim Adjie merupakan puskesmas yang memiliki layanan posyandu remaja. Posyandu remaja diadakan setiap hari sabtu jam 14.00 wib, kegiatan tersebut berupa 
penyuluhan pada remaja putri, serta pemeriksaan kesehatan lainnya. Alasan peneliti mengambil puskesmas ibrahim adjie, dikarenakan tempat yang strategis dan memiliki karakter responden yang sama yaitu usia 10-15 tahun. Pada fase ini usia dimana pada umumnya tanda-tanda sekunder mulai tampak, sudah dikatakan akil baligh karena adanya menstruasi.(Rosyda,2019)

Tujuan dalam penelitian ini adalah untuk mengetahui "Hubungan Stunting dengan Usia Menarche pada Remaja Putri Usia 10-15 tahun di Wilayah Kerja Posyandu Remaja Puskesmas Ibrahim Adjie.

\section{METODE PENELITIAN}

Studi analitik ini dilakukan dengan pendekatan Cross Sectional terhadap 81 remaja putri di wilayah kerja Posyandu remaja Puskesmas Ibrahim Adjie. Pengumpulan data dilakukan secara online dengan memberikan link Google Form. Data untuk menentukan status gizi $\mathrm{TB} / \mathrm{U}$ diolah dalam Software WHO Anthros Plus, dengan klasifikasi stunting Zscore $<-2$, san tidak stunting $\geq 2$.

Dalam penelitian ini digunakan uji chi kuadrat (chi square) untuk menentukan apakah terdapat hubungan antara stunting dengan usia menarche.

\section{HASIL DAN PEMBAHASAN}

Berdasarkan hasil penelitian mengenai hubungan stunting dengan usia menarche pada remaja putri usia 10-15 tahun pada responden yang memenuhi kriteria inklusi dan eksklusi yaitu sebanyak 81 remaja putri yang terdiri dari rw 5, 7, 8, 11 Cibangkong dan rw 8 Kebon Waru pada bulan juni 2020, didapatkan hasil sebagai berikut:

Tabel 1. Distribusi Frekuensi Stunting pada Remaja Putri Usia 10 —15 Tahun Di RW 5, 7, 8, 11 Cibangkong dan RW 8 Kebon Waru

\begin{tabular}{lcc}
\hline Status Gizi & Frekuensi & Persentasi \\
\hline Stunting & 16 & $19,8 \%$ \\
Tidak Stunting & 65 & $80,2 \%$ \\
\hline Total & 81 & $100 \%$ \\
\hline
\end{tabular}

Berdasarkan tabel 1, hasil penelitian menunjukan bahwa sebagian besar remaja putri usia 10-15 tahun di RW 5,6,7,8,11 Cibangkong dan RW 8 Kebon Waru sebagian besar tidak mengalami stunting dengan jumlah 65 responden $(80,2 \%)$. Hal ini bisa disebabkan karena pemenuhan gizi pada remaja yang baik. Remaja memerlukan zat gizi yang relatif besar dan seimbang jumlahnya sesuai kebutuhan, pada usia remaja masalah gizi biasanya berkaitan erat dengan gaya hidup dan kebiasaan makan yang juga terkait erat dengan perubahan fisik dan kebutuhan energi. Asupan gizi yang optimal, baik dalam hal kuantitas maupun kualitas sangat penting untuk pertumbuhan serta perkembangan yang optimal. 
Tabel 2. Distribusi Frekuensi Usia Menarche Pada Remaja Putri Usia 1015 Tahun di RW 5, 7, 8, 11 Cibangkong dan RW 8 Kebon Waru

\begin{tabular}{lcc}
\hline Status Gizi & Frekuensi & Persentasi \\
\hline Menarche Dini & 12 & $14,8 \%$ \\
\hline Menarche Normal & 43 & $53,1 \%$ \\
\hline $\begin{array}{l}\text { Menarche } \\
\text { Terlambat }\end{array}$ & 26 & $32,1 \%$ \\
\hline Total & 81 & $100 \%$ \\
\hline
\end{tabular}

Data menunjukan sebagian besar remaja putri usia 10-15 tahun mengalami menarche normal. Usia saat seorang anak perempuan mulai mendapatkan menarche sangat bervariasi, semua ini dipengaruhi oleh banyak faktor, antara lain faktor genetik, gizi, sosial, ekonomi dan lain lain. Di Indonesia sendiri menunjukan bahwa rata rata usia menarche di Indonesia adalah 12,5 tahun atau 13 tahun.

Tabel 3. Hubungan Stunting Dengan Usia Menarche Pada Remaja Putri Usia 10-15 Tahun di RW 5, 7, 8, 11 Cibangkong dan RW 8 Kebon Waru

\begin{tabular}{|c|c|c|c|c|c|c|c|}
\hline \multirow{3}{*}{$\begin{array}{l}\text { Status } \\
\text { Gizi }\end{array}$} & \multicolumn{6}{|c|}{ Usia Menarche } & $\mathrm{P}$ \\
\hline & \multicolumn{2}{|c|}{$\begin{array}{c}\text { Menarche } \\
\text { Dini }\end{array}$} & \multicolumn{2}{|c|}{$\begin{array}{c}\text { Menarche } \\
\text { Normal }\end{array}$} & \multicolumn{2}{|c|}{$\begin{array}{l}\text { Menarche } \\
\text { Terlambat }\end{array}$} & \multirow[t]{2}{*}{ value } \\
\hline & $\mathrm{P}$ & $\%$ & $\mathrm{P}$ & $\%$ & $\mathrm{P}$ & $\%$ & \\
\hline Stunting & 1 & 6,3 & 4 & 25 & 11 & 68,8 & 0,02 \\
\hline Tidak & 11 & 16,9 & 39 & 60 & 15 & 23,1 & \\
\hline Stunting & & & & & & & \\
\hline
\end{tabular}

Berdasarkan hasil analisis menggunakan uji chi square diperoleh nilai $\mathrm{p}=0,02$ dan $\alpha=0,05$ berarti $\mathrm{p}<\alpha$, maka Ho ditolak dan Ha diterima yang menyatakan terdapat hubungan antara stunting dengan usia menarche pada remaja putri usia 10-15 tahun di RW 5, 7, 8, 11 Cibangkong dan RW 8 Kebon Waru.

Hasil ini sesuai dengan penelitian $\mathrm{N}$. Amaliah, dkk (2012) terdapat hubungan status tinggi badan pendek beresiko (stunting) terhadap usia menarche pada remaja putri usia 10-15 tahun. Remaja putri yang bergizi baik mempunyai kecepatan pertumbuhan yang lebih tinggi pada masa sebelum pubertas (pra pubertas) dibandingkan dengan remaja yang kurang gizi. Remaja yang kurang gizi tumbuh lebih lambat untuk waktu yang lebih lama karena itu menarche juga tertunda.

Status gizi stunting akan mempengaruhi perkembangan reproduksi dan memperlambat masa pubertas, diantaranya adalah mengalami menarche terlambat. Hal ini karena pada stunting hormon yang dihasilkan oleh kelenjar hypotalamus, pituitary terhambat sehingga menyebabkan menarche terlambat. Terlambatnya usia menarche berhubungan dengan penurunan kesuburan dan fungsi reproduksi yang terlambat dalam jangka panjang akan meningkatkan risiko perempuan terserang osteoporosis karena lambatnya produksi estrogen yang akan mempengaruhi penentuan masa tulang.(Nurillah, 2012) Selain itu menarche terlambat menyebabkan menopause makin cepat, sehingga masa reproduksi 
menjadi lebih singkat.(Shah,2012) Akibat dari menopause mengakibatkan kadar estrogen dan progesteron turun dengan dramatis karena ovarium berhenti merespon FSH dan LH yang diproduksi oleh kelenjar hipofisis yang ada ditolak sehingga menyebabkan osteoporosis, gangguan kardiovaskuler, dan stroke yang disebabkan oleh defisiensi estrogen.(Hartono, 2012)

\section{KESIMPULAN DAN SARAN}

Terdapat hubungan antara stunting dengan usia menarche pada remaja putri usia 10-15 tahun di RW 5, 7, 8, 11 Cibangkong dan RW 8 Kebon Waru.

Disarankan untuk memberikan penyuluhan mengenai Pola Makan yang baik, Pentingnya Sarapan pada Remaja.

\section{DAFTAR PUSTAKA}

A Dwi, dkk. Hubungan Antara Status Gizi, Tingkat Pemaparan Media Masa dan Faktor Keturunan dengan Usia Menarche Pada Siswi di SMPN1 Subah Kabupaten Batang. 2014 Ilmu Kesehatan Universitas Muhammadiyah. Surakarta. 4- 16.

Hartono, soesanti. Berantas Stunting:Saat remaja diet sembarangan lahirkan anak stunting.2020 Jakarta: Grid Healthy Diaksestanggal 21 Februari 2020, jam 17. 01 WIB.

Nurillah, dkk. 2012. Status Tinggi Badan Pendek Beresiko Terhadap Keterlambatan Usia Menarche pada Perempuan Remaja usia 10-
15 Tahun. Jurnal Kesehatan Reproduksi. 35(2): 150-158.

Prawirohardjo, sarwono. 2010. Ilmu Kebidanan. Jakarta: PT. Bina Pustaka Sarwono

Proverawati, Atikah \& Misaroh,S. 2009. Menarche

Riset Kesehatan Dasar. Laporan Nasional Riset Kesehatan Dasar 2013.

Shah NR, Braverman ER. 2012. Measuring Adiposity in Patients: The Utility of Body Mass Index (BMII), Precent Body Fat, and Leptin. Plos One J. 4, 1-8.

Sudikn, Sandjaja. Evidence Of Downward Secular Trend In Age At Menarche Among Indonesian Women: Secondary Data Analisis Of Riskesdas 2010. Jurnal Kesehatan Reproduksi, 10(2), 2019:163-17 